\title{
Evapotranspiration estimation considering anthropogenic heat based on remote sensing in urban area
}

Article

Accepted Version

Cong, Z., Shen, Q., Zhou, L., Sun, T. and Liu, J. (2017) Evapotranspiration estimation considering anthropogenic heat based on remote sensing in urban area. Science in China Series D - Earth Sciences, 60 (4). pp. 659-671. ISSN 18622801 doi: https://doi.org/10.1007/s11430-016-0216-3 Available at https://centaur.reading.ac.uk/71099/

It is advisable to refer to the publisher's version if you intend to cite from the work. See Guidance on citing.

To link to this article DOI: http://dx.doi.org/10.1007/s11430-016-0216-3

Publisher: Springer

All outputs in CentAUR are protected by Intellectual Property Rights law, including copyright law. Copyright and IPR is retained by the creators or other copyright holders. Terms and conditions for use of this material are defined in the End User Agreement.

www.reading.ac.uk/centaur 
Central Archive at the University of Reading

Reading's research outputs online 


\section{Evapotranspiration estimation considering anthropogenic heat based}

on remote sensing in urban area

3 CONG ZhenTao ${ }^{1,2^{*}}$, SHEN QiNing ${ }^{1}$, ZHOU Lin ${ }^{1}$, SUN Ting ${ }^{1}$, LIU JiaHong ${ }^{3}$ 4

$5 \quad{ }^{1}$ State Key Laboratory of Hydro-Science and Engineering, Department of Hydraulic 6 Engineering, Tsinghua University, Beijing 100084, China

$7 \quad{ }^{2}$ Sanjiangyuan Collaborative Innovation Center, Tsinghua University, Beijing 100084, 8 China

$9{ }^{3}$ China Institute of Water Resources and Hydropower Research, Beijing 100038, China 10

*Corresponding Author (email: congzht@tsinghua.edu.cn) 


\section{Abstract}

22 Urbanization influences hydrologic cycle significantly on local, regional even global 23 scale. With urbanization the water resources demand for dense population sharpened, 24 thus it is a great challenge to ensure water supply for some metropolises such as Beijing. 25 Urban area is traditionally considered as the area with lower evapotranspiration (ET) 26 on account of the impervious surface and the lower wind speed. For most remote 27 sensing models, the ET, defined as latent heat in energy budget, is estimated as the difference between net radiation and sensible heat. The sensible heat is generally higher in urban area due to the high surface temperature caused by heat island, therefore the latent heat (i.e. the ET) in urban area is lower than that in other region. We estimated water consumption from 2003 to 2012 in Beijing based on water balance method and found that the annual mean ET in urban area was about $654 \mathrm{~mm}$. However, using Surface Energy Balance System (SEBS) model, the annual mean ET in urban area was only $348 \mathrm{~mm}$. We attributed this inconsistence to the impact of anthropogenic heat and quantified this impact on the basis of the night-light maps. Therefore, a new model SEBS-Urban, coupling SEBS model and anthropogenic heat was developed to estimate the ET in urban area. The ET in urban area of Beijing estimated by SEBS-Urban showed a good agreement with the ET from water balance method. The findings from this study highlighted that anthropogenic heat should be included in the surface energy budget for a highly urbanized area.

41 Keywords:

42 Urban; Evapotranspiration; SEBS; Remote sensing; Anthropogenic heat 


\section{Introduction}

Urbanization is progressing at a rapid rate on a global scale. Over half of population now lives in urban area, and by 2050 that fraction is expected to exceed $70 \%$ (Bratman et al., 2015; Heilig, 2012). Natural terrains are continuously converted to urban landscapes to meet the ever-increasing demand of the expanding urban population (Yang et al., 2015). The surface and atmospheric conditions in urban areas are modified, resulting in large variation of regional hydroclimate and energy balance (Oke, 2002; Tam et al., 2015; Yang et al., 2016; Zhang et al., 2009; Zhong et al., 2015). In addition, human activities make cities more vulnerable to a number of water resource problems (Bai and Imura, 2001; Iglesias et al., 2007; Jiang, 2009; Paul and Meyer, 2008). Therefore, further understanding of water cycle and energy balance in urban areas is necessary for future water resources planning.

Evapotranspiration (ET) is a combination of two processes: evaporation of liquid water from various surfaces and transpiration from the plants through stomata (Allen et al., 1998). It is a major component of water cycle and plays a vital role in surface energy balance system. In urban areas, ET research is central to green spaces irrigation, water consumption monitoring as well as the mechanism by which rainfall retention capacity is recovered between storm events. Common ET estimation procedures were developed for agricultural applications, however, researches on ET remained limited in urban areas (DiGiovanni et al., 2012; Grimmond and Oke, 1991; Zheng, 2012). In that regard, reliable estimation of urban ET is of particular importance for development of urban hydrology and water resource management.

A number of methods have been developed to estimate ET, including water balance method (Alley, 1984; Granier et al., 1999; Long and Singh, 2010; Palmroth et al., 2010; Senay et al., 2011; Xu and Singh, 2005), meteorological method (Alexandris et al., 2008; McMahon et al., 2013; Penman, 1948; Priestley and Taylor, 1972; Sumner and Jacobs, 2005) and remotely-sensed energy balance model (Allen et al., 2007; Bastiaanssen et al., 1998; Roerink et al., 2000; Su, 2002). For the acquisition of free information at all scales, remote sensing data has been extensively applied in numerous fields. The most popular remotely-sensed models include the Surface Energy Balance System (SEBS) (Su, 2002), the Surface Energy Balance Algorithm for Land (SEBAL) (Bastiaanssen et al., 1998), and the Mapping Evapotranspiration at High Resolution with Internalized Calibration (METRIC) (Allen et al., 2007), which have been widely used in ET estimation from regional to continental scales.

In ET estimation, remote sensing based methods provide a feasible alternative to the spatiotemporal characteristics of ET at different scales, which have advantages over the other approaches. In traditional remotely sensed models, the anthropogenic heat and net advection are negligible in energy balance equation. However, in cities anthropogenic heat from human metabolism, vehicles and building heat emissions is a significant contribution to the surface energy budget (Allen et al., 2011; McCarthy et al., 2010; Sailor, 2011). Anthropogenic heat is $0.028 \mathrm{~W} \mathrm{~m}^{-2}$ on global average, while localized estimation ranges from tens to hundreds of $\mathrm{W} \mathrm{m}^{-2}$ and even as high as 1590 $\mathrm{W} \mathrm{m}^{-2}$ for the extreme business district of Tokyo (Flanner, 2009; Ichinose et al., 1999; Kłysik, 1996; Pigeon et al., 2007; Sailor and Lu, 2004). Therefore, the impacts of anthropogenic heat are usually considerable and should be included in the surface energy budget for a highly urbanized area.

In this study, we hypothesize that ET was equal to the water consumption in the study area. The objectives of this study were (1) to estimate annual ET in Beijing based on water balance model and the original SEBS model; (2) to consider the influence of 
anthropogenic heat on ET in Beijing by a modified SEBS model (will be called as SEBS-Urban in the following); (3) to discuss the results and uncertainties in ET estimation.

This paper is organized as follows. The study area and data are given in the Section 2; Section 3 is the description of methods used (water balance method, SEBS model and SEBS-Urban model); the results and discussions are shown in Section 4; the conclusions are presented in Section 5.

\section{Study area and data}

\subsection{Study area}

Beijing $\left(115^{\circ} 25^{\prime} \sim 117^{\circ} 30^{\prime} \mathrm{E}, 39^{\circ} 26^{\prime} \sim 41^{\circ} 04^{\prime} \mathrm{N}\right)$, the capital of China, is located at North China Plain with a coverage of about $16410 \mathrm{~km}^{2}$ (see Figure 1a). The region has a typical temperate and monsoonal climate, with an annual mean rainfall of $576 \mathrm{~mm}$ and an annual mean temperature of about $12.5{ }^{\circ} \mathrm{C}$ from 1961 to 2010 ( $\mathrm{Li}$ and Yang, 2015; You et al., 2012). Beijing is the political and cultural center of China, with a history of over 3000 years and a permanent population of more than 20 million (Beijing Municipal Bureau of Statistics, 2012, website: http://www.bjstats.gov.cn/English/MR/ Population/ 201603/t20160303 337912.html). However, it is one of the most waterdeficient metropolises in the world. The per capita water resources available is about $150 \mathrm{~m}^{3}$ in Beijing in 2012, which is far below the international minimum standard of $1000 \mathrm{~m}^{3}$ per capita defined by the United Nations (Wang and Wang, 2005). There are many water regulation projects in the city and the Miyun reservoir is the primary project to ensure potable water for Beijing.

Woodland, farmland and urban land are the major land use types in Beijing (see Figure 1b) and the geography of the city is characterized by alluvial plains in the southeast and mountains in the north and west (see Figure 1c). In this study, Beijing was divided into a mountain area of $10174 \mathrm{~km}^{2}$ and a plain area of $6236 \mathrm{~km}^{2}$ in accordance with elevation and surface heterogeneity. Based on the land use data, the plain area was further subdivided into urban area and suburban area, which are changing over time with average of $1154 \mathrm{~km}^{2}$ and $5082 \mathrm{~km}^{2}$, respectively (see Figure 1a).

(a)

a)
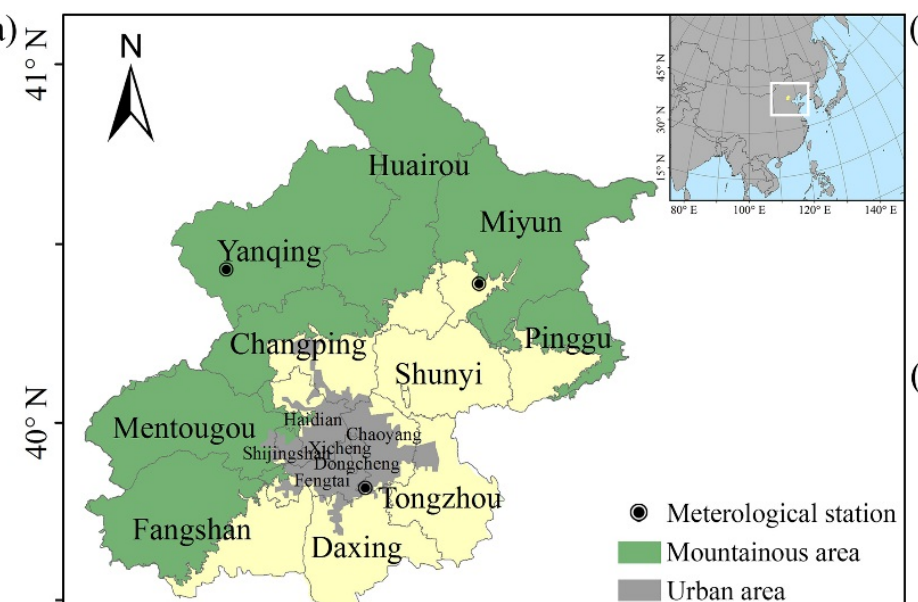

han

Daxing

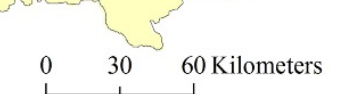

$116^{\circ} \mathrm{E}$

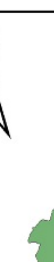

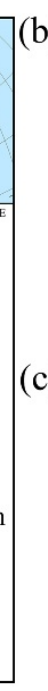

$118^{\circ} \mathrm{E}$

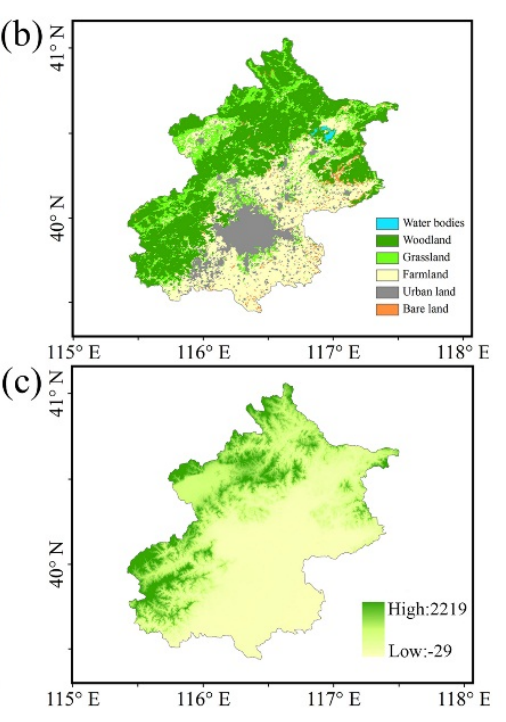

Figure 1. Information of the study area: (a) the location and the subareas of Beijing; (b) the land use map; (c) the elevation map. 


\subsubsection{Data for water balance method}

The data used in water balance method were mainly collected from the Beijing Water Resources Bulletin (Beijing Water Authority, website: http://www.bjwater.gov.cn/pub/bjwater/zfgk/tjxx/index 1.html) and Beijing Statistical Yearbook (Beijing Municipal Bureau of Statistics, website: http://www.bjstats. gov.cn/tjsj/). Due to the limited resources, the study concentrated on the period from 2003 to 2012. In addition, the divisional precipitation was estimated based on the combination of meteorological stations and local precipitation contour maps.

\subsubsection{Data for remote sensing models}

Remote sensing products are the key inputs to SEBS model. The information of the input data are listed in Table 1. In this study, emissivity, LAI, NDVI, LST and land use data were derived from MODIS standard products (website: http://reverb.echo.nasa.gov/). Land surface albedo was retrieved using the algorithm proposed by Liang (2001). NDVI values were scaled to fractional vegetation cover as follow (Gillies and Carlson, 1995):

$$
f_{c}=\frac{N D V I-N D V I_{\min }}{N D V I_{\max }-N D V I_{\min }}
$$

where $f_{c}$ is fractional vegetation cover, $N D V I_{\min }$ is the minimum $N D V I$, which can be estimated as the averaged $N D V I$ for bare soil, $N D V I_{\max }$ is the maximum $N D V I$, which can be estimated as the averaged $N D V I$ for forest.

Meteorological elements including air temperature, pressure, specific humidity, wind speed, downward shortwave radiation and downward longwave radiation were collected from China Meteorological Forcing Dataset (He and Yang, 2011). The evaluation of anthropogenic heat was based on the remote sensing nighttime lights data, a product of DMSP/OLS (website: http://ngdc.noaa.gov/eog/). All the information was interpolated into daily maps at $500 \mathrm{~m}$ resolution, using the linear interpolation method.

The quality of remote sensing image is affected by weather condition. In this study, only the cloud-free days with high-quality images of MODIS were selected for the analysis. The number of selected days in the study period are listed in Table 2.

Table 1. Information of the remote sensing data used in SEBS model.

\begin{tabular}{ccccc}
\hline Data & Source & $\begin{array}{c}\text { Spatial } \\
\text { resolution }\end{array}$ & $\begin{array}{c}\text { Temporal } \\
\text { resolution }\end{array}$ & Time period \\
\hline Emissivity & MOD11A1 & $1 \mathrm{~km}$ & Daily & $2003-2012$ \\
LAI & MOD15A2 & $1 \mathrm{~km}$ & 8 days & $2003-2012$ \\
NDVI & MOD13A2 & $1 \mathrm{~km}$ & 16 days & $2003-2012$ \\
LST & MOD11A1 & $1 \mathrm{~km}$ & Daily & $2003-2012$ \\
Land use & MCD12Q1 & $500 \mathrm{~m}$ & yearly & $2003-2012$ \\
Albedo & MOD09GA & $500 \mathrm{~m}$ & Daily & $2003-2012$ \\
Air temperature & China Meteorological Forcing & $0.1^{\circ} \times 0.1^{\circ}$ & $3 \mathrm{hr}$ & $2003-2012$ \\
Dataset & China Meteorological Forcing \\
Dataset & $0.1^{\circ} \times 0.1^{\circ}$ & $3 \mathrm{hr}$ & $2003-2012$
\end{tabular}




\begin{tabular}{ccccc} 
Specific humidity & $\begin{array}{c}\text { China Meteorological Forcing } \\
\text { Dataset }\end{array}$ & $0.1^{\circ} \times 0.1^{\circ}$ & $3 \mathrm{hr}$ & $2003-2012$ \\
Wind speed & $\begin{array}{c}\text { China Meteorological Forcing } \\
\text { Dataset }\end{array}$ & $0.1^{\circ} \times 0.1^{\circ}$ & $3 \mathrm{hr}$ & $2003-2012$ \\
$\begin{array}{c}\text { Downward shortwave } \\
\text { radiation }\end{array}$ & $\begin{array}{c}\text { China Meteorological Forcing } \\
\text { Dataset }\end{array}$ & $0.1^{\circ} \times 0.1^{\circ}$ & $3 \mathrm{hr}$ & $2003-2012$ \\
$\begin{array}{c}\text { Downward longwave } \\
\text { radiation }\end{array}$ & $\begin{array}{c}\text { China Meteorological Forcing } \\
\text { Dataset }\end{array}$ & $0.1^{\circ} \times 0.1^{\circ}$ & $3 \mathrm{hr}$ & $2003-2012$ \\
Nighttime lights data & DMSP/OLS & $1 \mathrm{~km}$ & yearly & $2003-2012$ \\
\hline
\end{tabular}

185

186

187

188

189

190

191

192

193

194

195

196

197

198

199

200

201

202

203

204

205

206

207

208

209

210

211

212

213

214

215

216

217

218

219

Table 2. The number of selected days in the study period (2003-2012).

\begin{tabular}{ccccccccccc}
\hline Year & 2003 & 2004 & 2005 & 2006 & 2007 & 2008 & 2009 & 2010 & 2011 & 2012 \\
\hline Number of days & 60 & 64 & 91 & 57 & 82 & 72 & 90 & 77 & 64 & 80 \\
\hline
\end{tabular}

\section{Methodology}

\subsection{Water balance method}

It was assumed that ET was equal to the water consumption in the study area. Based on the water balance equation, the annual ET can be estimated as follow:

$$
\begin{gathered}
E T=P+10^{5}\left(S_{i}-S_{o}+G_{i}-G_{o}-\Delta S-\Delta G\right) / A \\
E T_{m}=P_{m}+10^{5}\left(S_{m i}-S_{m o}+G_{m i}-G_{m o}-\Delta S_{m}-\Delta G_{m}\right) / A_{m} \\
E T_{p}=P_{p}+10^{5}\left(S_{p i}-S_{p o}+G_{p i}-G_{p o}-\Delta S_{p}-\Delta G_{p}\right) / A_{p} \\
E T_{u}=P_{u}+10^{5}\left(S_{u i}-S_{u o}+G_{u i}-G_{u o}-\Delta S_{u}-\Delta G_{u}\right) / A_{u} \\
E T_{s}=P_{s}+10^{5}\left(S_{s i}-S_{s o}+G_{s i}-G_{s o}-\Delta S_{s}-\Delta G_{s}\right) / A_{s}
\end{gathered}
$$

Eq. (2) to Eq. (6) are for the entire area, mountainous area, plain area, urban area and suburb area, respectively, where $E T$ is the annual evapotranspiration, $\mathrm{mm} ; P$ is the annual precipitation, $\mathrm{mm} ; S_{i}$ is the annual surface inflow, i.e. the supply from runoff and South-North Water Transfer Project, $10^{8} \mathrm{~m}^{3} ; S_{o}$ is the annual surface outflow, $10^{8} \mathrm{~m}^{3} ; G_{i}$ is the annual groundwater input, $10^{8} \mathrm{~m}^{3} ; G_{o}$ is the annual groundwater outflow, $10^{8} \mathrm{~m}^{3}$, and it was assumed that $G_{o}$ equaled $G_{i}$ in this study; $\Delta S$ is the variation in surface water storage, $10^{8} \mathrm{~m}^{3}$, estimating from change in reservoir storage; $\Delta G$ is the variation in groundwater storage, $10^{8} \mathrm{~m}^{3} ; A$ is the corresponding area, $\mathrm{km}^{2}$.

Figure 2 shows the water balance of subareas in Beijing. Note that in mountainous area, $S_{m i}$ was estimated as the annual runoff supply; $S_{m o}$ was calculated as surface water resources in mountainous area; $G_{m i}$ was equal to $G_{i}$; $G_{m o}$ was regarded as water supply from mountainous area to plain area; $\Delta G_{m}$ was generally neglected due to few extraction of groundwater and the self-adjustment of ecosystem; and $\Delta S_{m}$ was equal to $\Delta S$. When it comes to plain area, $S_{p i}$ was considered as the sum of $S_{m o}$ and annual supply from South-North Water Transfer Project; $S_{p o}, G_{p i}, G_{p o}$ and $\Delta G_{p}$ were equal to $S_{o}, G_{m o}, G_{o}$, and $\Delta G$, respectively; and $\Delta S_{p}$ was neglected considering that there were few large scale reservoirs in plain area. As for urban area, $S_{u i}$ was estimated as the difference between water supply (includes industrial, domestic and ecological water use) and underground water exploited in urban area; $S_{u o}$ was considered as urban drainage; $G_{u i}$ was estimated according to the underground supply from mountainous area; $G_{u o}$ was neglected due to the intensive extraction of underground water in urban area; $\Delta G_{u}$ was calculated as $\Delta G_{u}=\Delta G \times A_{u} / A_{p}$; and $\Delta S_{u}$ was neglected. With regard to suburb area, $S_{s i}, S_{s o}, G_{s i}, G_{s o}$ $\Delta G_{s}$ and $\Delta S_{s}$ were calculated as the differences between the corresponding items in plain 
area and urban area.

(a)

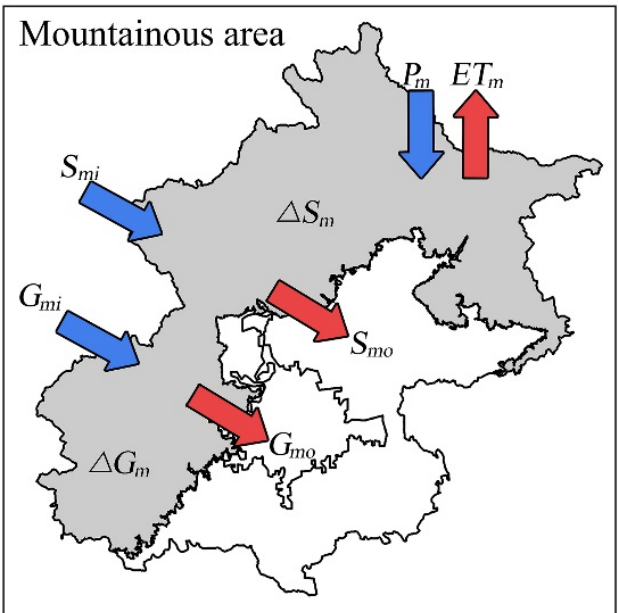

(c)

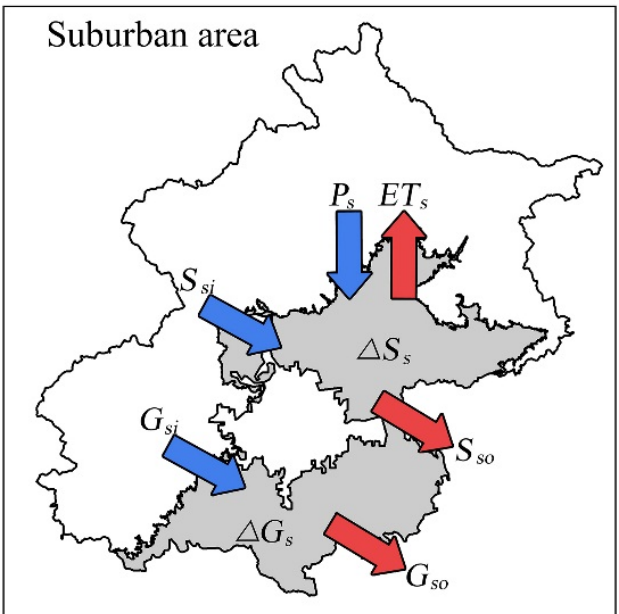

(b)

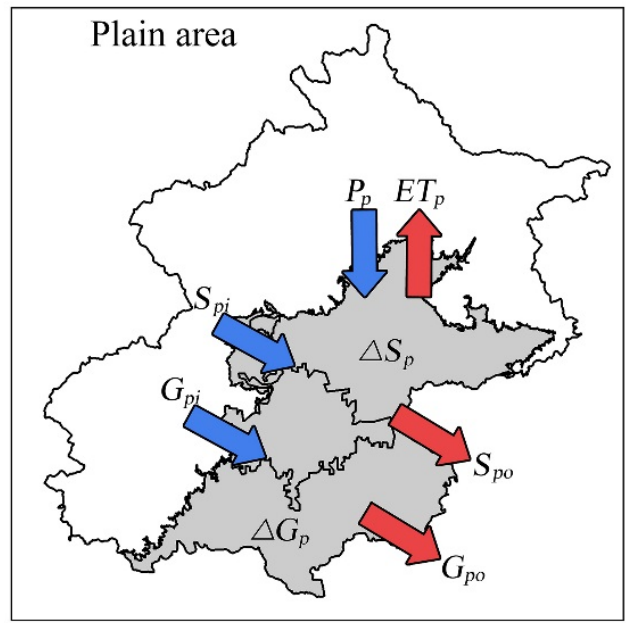

(d)

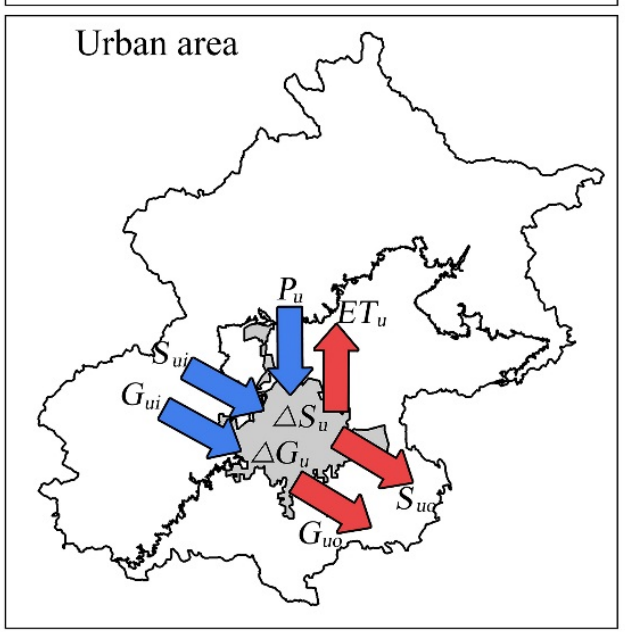

Figure 2. Water balance of subareas in Beijing. Blue arrows and red arrows represent water input and output, respectively.

\subsection{Surface Energy Balance System (SEBS) model}

The Surface Energy Balance System (SEBS) was developed by Su (2002) for the estimation of turbulent heat fluxes and the daily evapotranspiration using remote sensing data. Only the main SEBS equations and concepts are presented in this paper, further details were given by Su et al. (2001) and Su (2002). The SEBS algorithm is based on the energy balance equation expressed as:

$$
R_{n}=G_{0}+H+\lambda E T
$$

where $R_{n}$ is net radiation, $\mathrm{W} \mathrm{m}^{-2} ; G_{0}$ is soil heat flux, $\mathrm{W} \mathrm{m}^{-2} ; H$ is sensible heat flux, $\mathrm{W} \mathrm{m} \mathrm{m}^{-2}$ and $\lambda E T$ is the latent heat flux, $\mathrm{W} \mathrm{m}^{-2}$ ( $\lambda$ is the latent heat of vapourization and $E T$ is evapotranspiration). $R_{n}$ is calculated by:

$$
R_{n}=(1-\alpha) \cdot R_{s w d}+\varepsilon \cdot R_{l w d}-\varepsilon \cdot \sigma \cdot T_{0}^{4}
$$

where $\alpha$ is albedo, $R_{s w d}$ is downward shortwave radiation, $\mathrm{W} \mathrm{m} \mathrm{m}^{-2} ; R_{l w d}$ is downward longwave radiation, $\mathrm{W} \mathrm{m}^{-2} ; \varepsilon$ is emissivity; $\sigma$ is the Stefan-Boltzmann constant, $\mathrm{W} \mathrm{m}^{-2} \mathrm{~K}^{-4}$; and $T_{0}$ is surface temperature, $\mathrm{K}$.

The soil heat flux is calculated taking into account fractional vegetation cover:

$$
G_{0}=R_{n} \cdot\left[\Gamma_{c}+\left(1-f_{c}\right) \cdot\left(\Gamma_{s}-\Gamma_{c}\right)\right]
$$


where $f_{c}$ is fractional vegetation cover; $\Gamma_{c}=0.05$ (dimensionless) for full vegetation cover and $\Gamma_{s}=0.315$ (dimensionless) for bare soil. An interpolation is then performed between the two limiting cases based on $f_{c}$.

For deriving the sensible and latent heat flux, the similarity theory was used. In SEBS model, distinction were made between the Atmospheric Boundary Layer (ABL) and the Atmospheric Surface Layer (ASL). Since the field measurements were performed in ASL, the Monin-Obukhov Similarity (MOS) functions by Brutsaert (1999) were used. For stable conditions in ASL, the equations proposed by Beljaars and Holtslag (1991) and Van den Hurk and Holtslag (1997) were used, while in ABL the functions proposed by Brutsaert (1982) were used. The MOS expressions are not presented in this paper.

The roughness height for momentum transfer and roughness height for heat transfer were calculated taking into account the canopy height $h$ and reference height $z_{\text {ref }}$. The equations were given by Su $(2001 ; 2002)$ based on surface layer similarity theory (Brutsaert, 1982):

$$
\begin{gathered}
z_{0 m}=h \cdot\left(1-d_{0} / h\right) \cdot e^{-k u(h) / u_{*}} \\
d_{0} / h=1-\left(1-e^{-2 n_{e c}}\right) / 2 n_{e c} \\
n_{e c}=C_{d} \cdot L A I /\left(2 u_{*}^{2} / u(h)^{2}\right) \\
u(h)=u_{r e f} \frac{\ln \left(h-d / z_{0 m}\right)}{\ln \left(z_{r e f}-d / z_{0 m}\right)} \\
z_{0 h}=z_{0 m} / e^{k B^{-1}}
\end{gathered}
$$

where $z_{0 m}$ is the roughness height for momentum transfer; $h$ is the canopy height; $d_{0}$ is the displacement height; $k$ is the von Karman constant with a numeric value of $0.4 ; u(h)$ is the horizontal wind speed at the canopy top; $u_{*}$ is the friction velocity; $n_{e c}$ is the within-canopy wind speed profile extinction; $C_{d}$ is the drag coefficient taken as $0.2 ; L A I$ is the leaf area index; $u_{r e f}$ is the reference wind speed; $z_{r e f}$ is the reference height; and $B^{-1}$ is the inverse Stanton number. See $\mathrm{Su}$ (2002) for more details.

In this study, the essential parameter $h$ was estimated in accordance with different land use types from MODIS. The land use types were reclassified into 10 types based

\begin{tabular}{|c|c|c|c|c|c|}
\hline $\begin{array}{l}\text { Code in } \\
\text { MODIS }\end{array}$ & Class name & Recode & Rename & $h$ & Reference \\
\hline 0 & Water Bodies & 0 & $\begin{array}{l}\text { Water } \\
\text { Bodies }\end{array}$ & 0.0001 & --- \\
\hline 1 & $\begin{array}{c}\text { Evergreen Needleleaf } \\
\text { Forest }\end{array}$ & 1 & $\begin{array}{c}\text { Evergreen } \\
\text { Forest }\end{array}$ & $10 \sim 12$ & $\begin{array}{l}\text { (Che, 2008; Zhang et } \\
\text { al., 2014; Zhang, 2011) }\end{array}$ \\
\hline 3 & $\begin{array}{c}\text { Deciduous Needleleaf } \\
\text { Forest }\end{array}$ & 2 & $\begin{array}{l}\text { Deciduous } \\
\text { Forest }\end{array}$ & $10 \sim 12$ & $\begin{array}{l}\text { (Che, 2008; Zhang et } \\
\text { al., 2014; Zhang, 2011) }\end{array}$ \\
\hline 4 & $\begin{array}{c}\text { Deciduous Broadleaf } \\
\text { Forest }\end{array}$ & 2 & $\begin{array}{l}\text { Deciduous } \\
\text { Forest }\end{array}$ & $10 \sim 12$ & $\begin{array}{l}\text { (Che, 2008; Zhang et } \\
\text { al., 2014; Zhang, 2011) }\end{array}$ \\
\hline 5 & Mixed Forest & 3 & $\begin{array}{l}\text { Mixed } \\
\text { Forest }\end{array}$ & $10 \sim 12$ & $\begin{array}{l}\text { (Che, 2008; Zhang et } \\
\text { al., 2014; Zhang, 2011) }\end{array}$ \\
\hline
\end{tabular}
on the definition given by International Geosphere-Biosphere Programme (IGBP) and the corresponding values of canopy height were obtained from relative researches in Beijing (see Table 3).

Table 3. The values of the parameter $h$ in this study. 


\begin{tabular}{|c|c|c|c|c|c|}
\hline 6 & Closed Shrublands & 4 & Shrublands & $1.2 \sim 2.5$ & $\begin{array}{l}\text { (Che, 2008; Du and } \\
\text { Xing, 2009) }\end{array}$ \\
\hline 7 & Open Shrublands & 4 & Shrublands & $1.2 \sim 2.5$ & $\begin{array}{l}\text { (Che, 2008; Du and } \\
\text { Xing, 2009) }\end{array}$ \\
\hline 8 & Woody Savannas & 5 & Grasslands & $0.005 \sim 0.03$ & (Xu et al., 2009) \\
\hline 9 & Savannas & 5 & Grasslands & $0.005 \sim 0.03$ & (Xu et al., 2009) \\
\hline 10 & Grasslands & 5 & Grasslands & $0.005 \sim 0.03$ & (Xu et al., 2009) \\
\hline 11 & Permanent Wetlands & 6 & Wetlands & 0.0001 & --- \\
\hline 12 & Croplands & 7 & Croplands & $0.003 \sim 1$ & (Song et al., 2009) \\
\hline 13 & Urban and Built-Up & 8 & Urban & 20 & $\begin{array}{c}\text { (He et al., 2001; Shi et } \\
\text { al., 2015) }\end{array}$ \\
\hline 14 & $\begin{array}{l}\text { Cropland/Natural } \\
\text { Vegetation Mosaic }\end{array}$ & 9 & Bare land & 0.0005 & --- \\
\hline 15 & Snow and Ice & 9 & Bare land & 0.0005 & --- \\
\hline 16 & $\begin{array}{c}\text { Barren or Sparsely } \\
\text { Vegetated }\end{array}$ & 9 & Bare land & 0.0005 & --- \\
\hline
\end{tabular}

The value of $H$ was then determined by considering the dry-limit and wet-limit conditions. Under dry-limit condition (soil moisture at limiting cases), the latent heat becomes zero while the sensible heat flux is at its maximum value. By definition, from Eq. (7), it follows that:

$$
\lambda E T_{d r y}=R_{n}-G_{0}-H_{d r y} \equiv 0 \text { or } H_{d r y}=R_{n}-G_{0}
$$

Under wet-limit condition (energy at limiting cases), ET occurs at the potential rate, while sensible heat flux takes its minimum value, which therefore follows:

$$
\lambda E T_{\text {wet }}=R_{n}-G_{0}-H_{\text {wet }} \text { or } H_{\text {wet }}=R_{n}-G_{0}-\lambda E T_{\text {wet }}
$$

Then the evaporative fraction, $\Lambda$ was expressed as:

$$
\Lambda=\frac{\lambda E T}{R_{n}-G_{0}}
$$

By inverting Eq. (12), the latent heat can be calculated as:

$$
\lambda E=\Lambda \cdot\left(R_{n}-G_{0}\right)
$$

Actual ET converted to water depth in mm per time unit was then calculated by $E T=\lambda E T /\left(\lambda \cdot \rho_{w}\right)$, where $\rho_{w}$ is the density of water $\mathrm{kg} \mathrm{m}^{-3}$ (Jia et al., 2009).

Note that satellite images provide for the instantaneous observation in time, therefore, daily ET was derived by assuming that the evaporative fraction remain constant throughout the day (Jia et al., 2009; Sugita and Brutsaert, 1991). The daily ET was then given by:

$$
\begin{aligned}
E T_{\text {daily }} & =\sum_{i=0}^{24}\left[\Lambda \cdot \frac{R_{n}-G}{\lambda \rho_{w}}\right] \\
& =24(\mathrm{~h}) \cdot 3600(\mathrm{~s}) \cdot\left[\Lambda \cdot \frac{R_{\text {ndaily }}-G_{\text {daily }}}{\lambda \rho_{w}}\right] \\
& =8.67 \times 10^{7} \cdot\left[\Lambda \cdot \frac{R_{\text {ndaily }}-G_{\text {daily }}}{\lambda \rho_{w}}\right]
\end{aligned}
$$

where $E T_{\text {daily }}$ is the daily evapotranspiration, $\mathrm{mm} ; R_{\text {ndaily }}$ is the daily mean net 
radiation, $\mathrm{W} \mathrm{m}^{-2} ; ; G_{\text {daily }}$ is the daily mean soil surface heat flux, $\mathrm{W} \mathrm{m}^{-2} ; \rho_{w}$ is the density of water, $\mathrm{kg} \mathrm{m}^{-3} ; \lambda$ is the latent heat of vapourization taken as $2.45 \times 10^{6} \mathrm{~J} \mathrm{~kg}^{-1}$.

Since the ET was estimated from discrete remote sensing images, to produce time series of ET, the crop coefficient method proposed by Allen (2000) was used for reference in this study. Researches indicate that crop coefficient method is generally sufficient to estimate time series of ET, also on a monthly basis (Morse et al., 2000; Allen et al., 2001; Allen et al., 2007). Thus this method is considered valid for extending ET series in Beijing, where the image intervals are no more than two weeks.

The crop coefficient is basically the ratio of actual ET to the reference evapotranspiration $\left(\mathrm{ET}_{0}\right)$. The crop coefficient method interpolated the crop coefficients derived from remotely sensed actual ET and corresponding $\mathrm{ET}_{0}$ for the days of image available. Then combining the interpolated crop coefficient with $\mathrm{ET}_{0}$, actual ET for days without good quality images could be inferred, which was formulated as:

$$
E T_{\text {period }}=\sum_{i=b}^{f}\left[\frac{1}{2}\left(\frac{E T_{b}}{E T_{0 b}}+\frac{E T_{f}}{E T_{0 f}}\right)\left(E T_{0 i}\right)\right]
$$

where $E T_{\text {period }}$ represents the accumulated actual ET for a period with beginning day $b$ and ending day $f$, which are cloud-free days; $E T_{b}$ and $E T_{f}$ are the actual ET derived from the beginning day and ending day, respectively; $E T_{0 b}$ and $E T_{0 f}$ are the corresponding reference ET for the beginning day and ending day, respectively; and $E T_{0 i}$ is the reference ET for day $i$. In this study, the reference ET was calculated using FAO-Penman-Monteith equation (Allen et al., 1998).

\subsection{SEBS-Urban model}

In traditional remote sensing-based models, the anthropogenic heat and net advection are neglected in energy balance equation. However, in metropolis with intensive human activities, anthropogenic heat would contribute significantly to the surface energy budget (Allen et al., 2011; McCarthy et al., 2010; Sailor, 2011). High anthropogenic heat is generally observed in Beijing and in the densely built-up areas the hourly maximum value even as high as $474.3 \mathrm{~W} \mathrm{~m}^{-2}$. (Nie et al., 2014; Tong et al., 2004). In this section, anthropogenic heat was quantified to estimate ET in Beijing by a modified SEBS model. Therefore, the energy balance equation was given as:

$$
R_{n}+Q_{f}=G_{0}+H+\lambda E T
$$

where $R_{n}$ is net radiation, $\mathrm{W} \mathrm{m}^{-2} ; Q_{f}$ is anthropogenic heat, $\mathrm{W} \mathrm{m}^{-2} ; G_{0}$ is soil heat flux, $\mathrm{W} \mathrm{m}^{-2} ; H$ is sensible heat flux, $\mathrm{W} \mathrm{m}^{-2}$ and $\lambda E T$ is the latent heat flux, $\mathrm{W}$ $\mathrm{m}^{-2}$.

The evaluation of anthropogenic heat was based on the remote sensing product of DMSP/OLS, which provide annual averaged nighttime lights maps with numeric values range from 0 to 63 . In this study, the threshold value was defined as 52 for separating the anthropogenic heat-impacted areas from the anthropogenic heat-free areas (Shu et al., 2011). The values of anthropogenic heat were set as a range from $50 \mathrm{~W} \mathrm{~m}^{-2}$ to 75 $\mathrm{W} \mathrm{m} \mathrm{m}^{-2}$ for summer and winter, and $30 \mathrm{~W} \mathrm{~m}^{-2}$ to $50 \mathrm{~W} \mathrm{~m}^{-2}$ for spring and autumn, on the basis of researches conducted by Nie et al. (2014) and Tong et al. (2004). Then the corresponding light intensity limits were 52 and 63 and the internal values were produced by linear interpolation. Therefore, the value of anthropogenic heat was given as:

$$
Q_{f 1}=Q_{f l 1}+\left(I-I_{\min }\right) \cdot \frac{Q_{f u 1}-Q_{f l 1}}{I_{\max }-I_{\min }}
$$




$$
Q_{f 2}=Q_{f l 2}+\left(I-I_{\min }\right) \cdot \frac{Q_{f u 2}-Q_{f l 2}}{I_{\text {max }}-I_{\text {min }}}
$$

Eq. (22) is for summer and winter, where $Q_{f 1}$ is the anthropogenic heat, $\mathrm{W} \mathrm{m}^{-2}$; $Q_{f l l}\left(50 \mathrm{~W} \mathrm{~m}^{-2}\right)$ and $Q_{f u l}\left(75 \mathrm{~W} \mathrm{~m}^{-2}\right)$ are the lower limit and upper limit of anthropogenic heat, respectively; $I$ is the numeric value of light intensity; $I_{\max }$ is the maximum light intensity with a value of $63 ; I_{\min }$ is the minimum light intensity set as 52 , i.e. the threshold value for identifying the anthropogenic heat-impacted areas.

Eq. (23) is for spring and autumn, where $Q_{f l 2}\left(30 \mathrm{~W} \mathrm{~m}^{-2}\right)$ and $Q_{f u 2}\left(50 \mathrm{~W} \mathrm{~m}^{-2}\right)$ are the lower limit and upper limit of anthropogenic heat, respectively; and the other items are set ibid.

\section{Results and discussions}

\subsection{ET estimated by water balance method}

ET estimation of each subarea based on water balance method from 2003 to 2012 are listed in Table 4. It can be seen that the average ET in Beijing from 2003 to 2012 was $517 \mathrm{~mm}$, which was roughly equivalent to average precipitation of $523 \mathrm{~mm}$. This indicates that Beijing made little contribution to the water resources of Hai River Basin. It should be noted that averaged annual ET in urban area was the highest among all subareas $(654 \mathrm{~mm})$, while the lowest in mountainous area $(472 \mathrm{~mm})$. Figure 3a and Figure 3b shows the averaged ET and water input/output over the decade in entire Beijing and urban area, respectively. According to Figure 3, precipitation made up most of ET in entire Beijing at a long-term scale, however, as for urban area surface inflow and precipitation both contributed greatly to ET. Figure 4 illustrates the time series of ET estimated by water balance method in subareas of Beijing from 2003 to 2012. It can also be observed that ET in urban area was generally higher than other areas. Additionally, relative smooth changes in ET were observed in plain area and suburban area, while a dramatic variation was shown in mountainous area. This may be attributed to the significant fluctuation of rainfall received in mountain region.

(a)

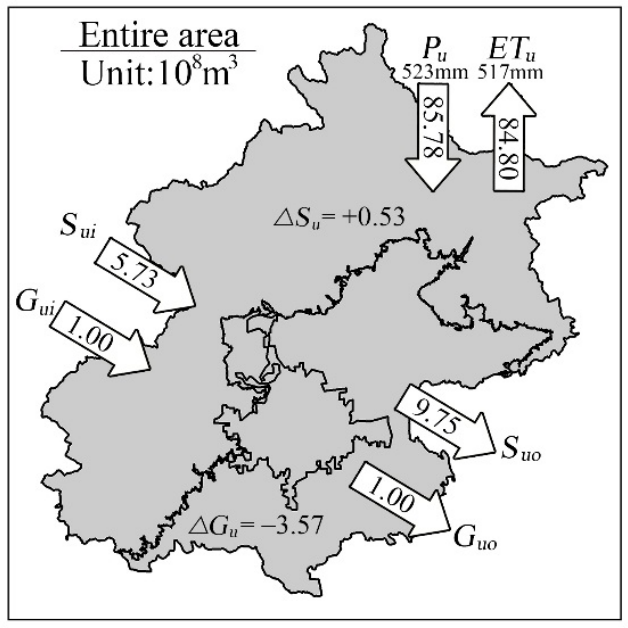

(b)

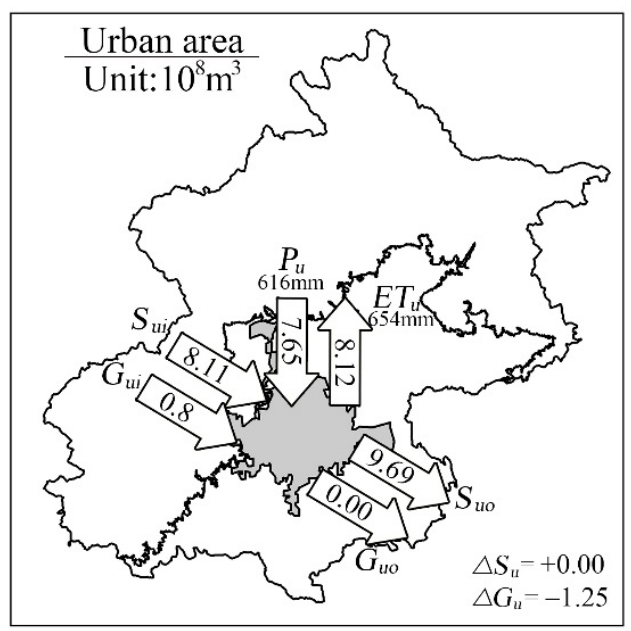

Figure 3. Averaged annual precipitation and ET in entire Beijing and urban area over 2003 to 2012 . 


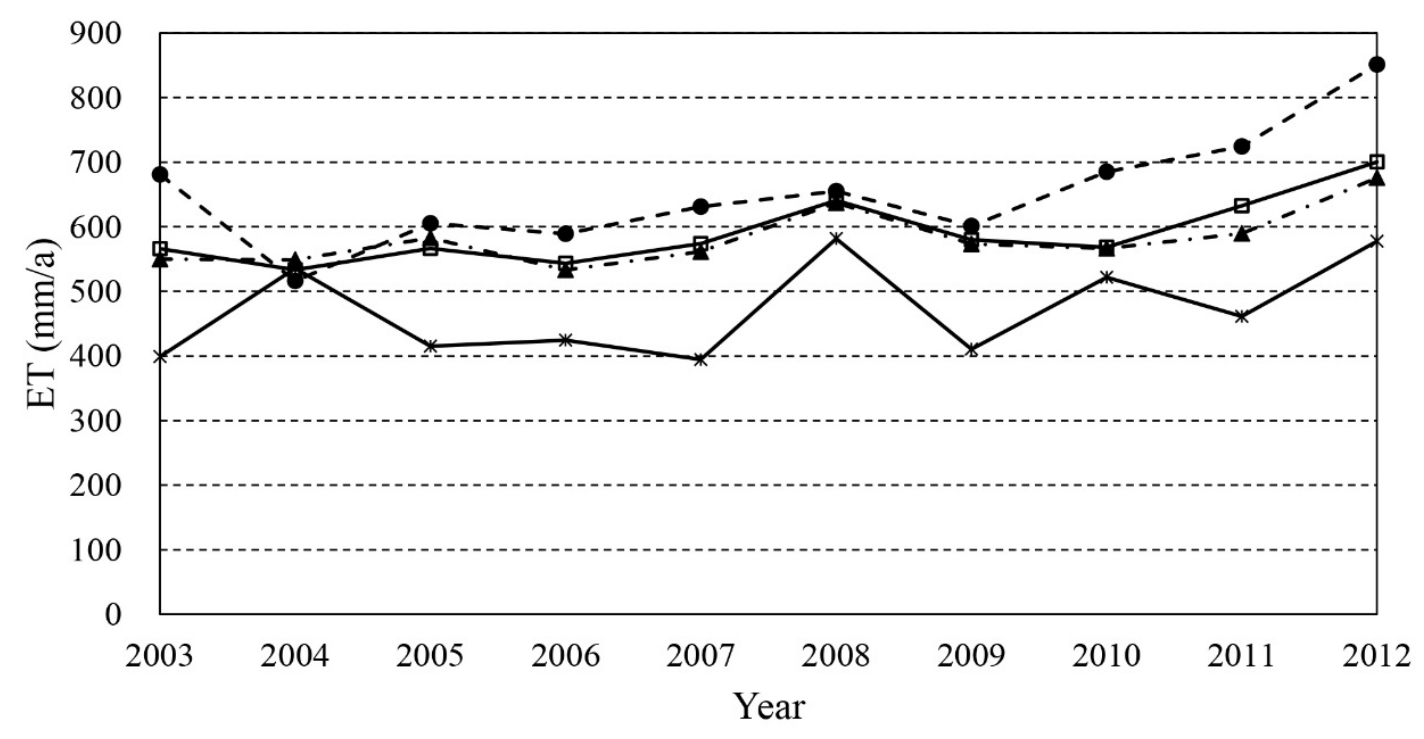

Figure 4. Time series of ET estimation from water balance method in subareas of Beijing during 2003-2012.

Table 4 Annual precipitation and ET estimation using SEBS, SEBS-Urban and water balance method ( $\mathrm{mm})$.

\begin{tabular}{|c|c|c|c|c|c|c|c|c|c|c|c|c|}
\hline Year & & 2003 & 2004 & 2005 & 2006 & 2007 & 2008 & 2009 & 2010 & 2011 & 2012 & Average \\
\hline \multirow{4}{*}{ Entire area } & $\begin{array}{c}\text { Water } \\
\text { balance }\end{array}$ & 453 & 534 & 474 & 471 & 472 & 603 & 476 & 538 & 521 & 625 & 517 \\
\hline & SEBS & 564 & 510 & 541 & 490 & 461 & 549 & 500 & 523 & 551 & 581 & 527 \\
\hline & $\begin{array}{l}\text { SEBS- } \\
\text { Urban }\end{array}$ & 592 & 546 & 574 & 529 & 506 & 595 & 543 & 586 & 607 & 643 & 572 \\
\hline & $\mathrm{P}$ & 453 & 539 & 468 & 448 & 449 & 638 & 448 & 524 & 552 & 708 & 523 \\
\hline \multirow{4}{*}{$\begin{array}{l}\text { Mountainous } \\
\text { area }\end{array}$} & $\begin{array}{c}\text { Water } \\
\text { balance }\end{array}$ & 399 & 536 & 415 & 424 & 395 & 582 & 410 & 522 & 461 & 578 & 472 \\
\hline & SEBS & 581 & 540 & 561 & 513 & 478 & 566 & 509 & 545 & 578 & 587 & 546 \\
\hline & $\begin{array}{l}\text { SEBS- } \\
\text { Urban }\end{array}$ & 582 & 542 & 563 & 516 & 481 & 568 & 511 & 550 & 581 & 593 & 549 \\
\hline & $\mathrm{P}_{\mathrm{m}}$ & 425 & 558 & 442 & 434 & 407 & 648 & 419 & 542 & 492 & 652 & 502 \\
\hline \multirow{4}{*}{ Plain area } & $\begin{array}{c}\text { Water } \\
\text { balance }\end{array}$ & 566 & 533 & 567 & 544 & 574 & 641 & 580 & 568 & 632 & 700 & 591 \\
\hline & SEBS & 538 & 462 & 508 & 452 & 433 & 523 & 485 & 488 & 507 & 571 & 497 \\
\hline & $\begin{array}{l}\text { SEBS- } \\
\text { Urban }\end{array}$ & 607 & 553 & 590 & 550 & 547 & 637 & 596 & 644 & 650 & 725 & 610 \\
\hline & $P_{p}$ & 525 & 510 & 510 & 470 & 495 & 625 & 494 & 501 & 665 & 796 & 559 \\
\hline \multirow{4}{*}{ Urban area } & $\begin{array}{c}\text { Water } \\
\text { balance }\end{array}$ & 681 & 516 & 605 & 589 & 631 & 655 & 601 & 685 & 724 & 851 & 654 \\
\hline & SEBS & 395 & 270 & 328 & 305 & 297 & 372 & 301 & 329 & 361 & 518 & 348 \\
\hline & $\begin{array}{l}\text { SEBS- } \\
\text { Urban }\end{array}$ & 665 & 537 & 591 & 607 & 613 & 679 & 594 & 658 & 698 & 882 & 652 \\
\hline & $\mathrm{P}_{\mathrm{u}}$ & 634 & 602 & 450 & 505 & 558 & 680 & 496 & 622 & 743 & 911 & 620 \\
\hline \multirow{4}{*}{$\begin{array}{l}\text { Suburban } \\
\text { area }\end{array}$} & $\begin{array}{c}\text { Water } \\
\text { balance }\end{array}$ & 550 & 549 & 582 & 533 & 561 & 637 & 573 & 566 & 589 & 676 & 582 \\
\hline & SEBS & 569 & 504 & 547 & 484 & 463 & 555 & 524 & 523 & 538 & 582 & 529 \\
\hline & $\begin{array}{l}\text { SEBS- } \\
\text { Urban }\end{array}$ & 593 & 556 & 589 & 536 & 532 & 627 & 595 & 640 & 638 & 691 & 600 \\
\hline & $\mathrm{P}_{\mathrm{s}}$ & 510 & 501 & 548 & 462 & 481 & 611 & 493 & 498 & 634 & 780 & 552 \\
\hline
\end{tabular}




\subsection{ET estimated by original SEBS}

The annual ET values estimated from original SEBS are listed in Table 4. It represents a contrary results from water balance method that mountainous area has the highest average ET of $546 \mathrm{~mm}$, while urban area has the lowest average ET of $348 \mathrm{~mm}$. In this study, 2003, 2006, 2009 and 2012 had been selected as the typical years for comparison. The spatial variability of annual ET was significant large over the entire Beijing and the lowest ET was found in urban area (see Figure 5).

\subsection{ET estimated by SEBS-Urban}

The annual ET calculated using SEBS-Urban are listed in Table 4. It can be seen that annual ET in urban area was the highest among all subareas $(652 \mathrm{~mm})$, while the lowest in mountainous area $(549 \mathrm{~mm})$, which was coincident with the result from water balance method. ET spatial patterns vary dramatically over the entire Beijing as illustrated by Figure 5. It can be observed that higher ET values across the study region were yielded in urban area, and an increasingly trend was also observed from 2003 to 2012.
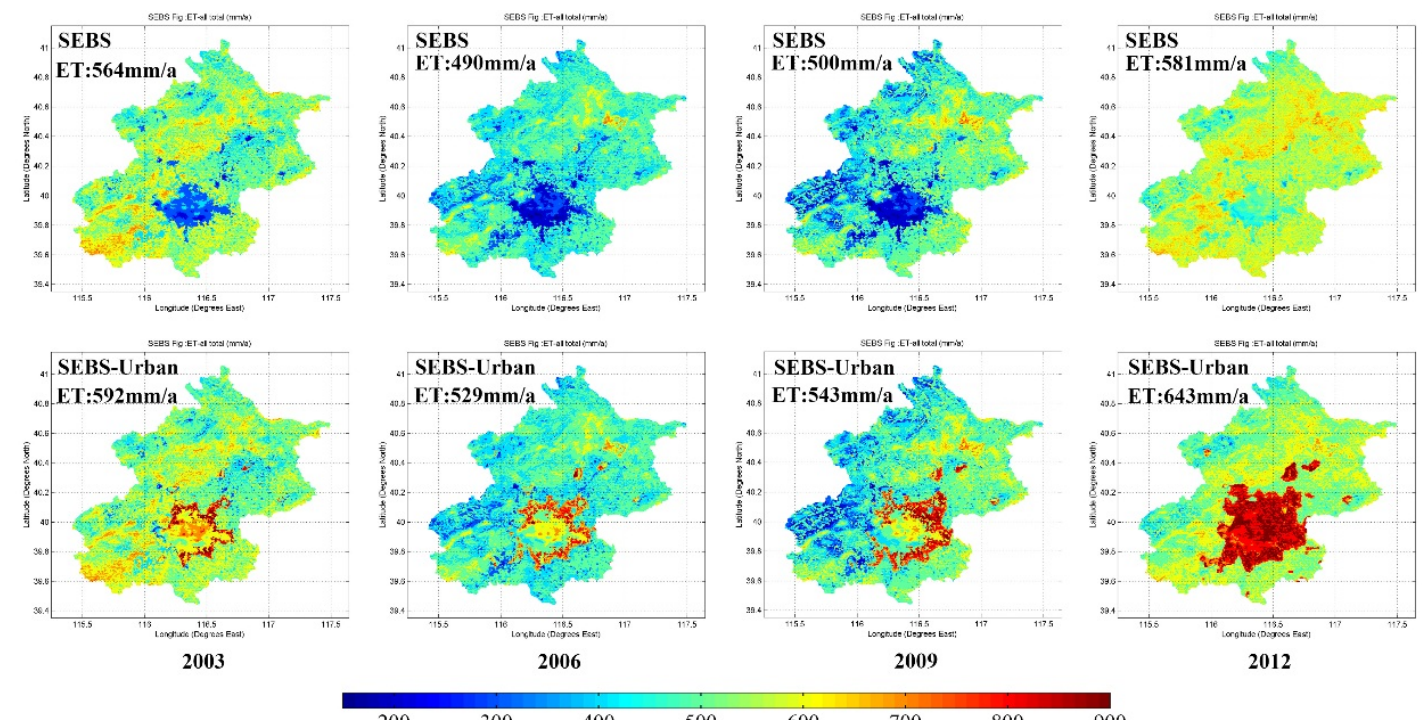

200

600

2012

Figure 5. Annual values and spatial distribution of ET estimation using SEBS and SEBS-Urban in the typical years.

\subsection{Comparison of ET estimated by different methods}

The relationships between ET estimation from water balance method and remotely-sensed models in subareas of Beijing from 2003 to 2012 are demonstrated in Figure 6, and the corresponding ET values are given in Table 4. It should be noted that averaged annual ET in urban area was the highest among all subareas using water balance method $(654 \mathrm{~mm})$ and SEBE-Urban $(652 \mathrm{~mm})$. The anthropogenic heatimpacted areas were extracted from the night-light maps with a numeric value greater than 52, and the variation is demonstrated in Figure 7 and Figure 8. From Figure 7, it can be seen that in 2003, the extreme values of anthropogenic heat were mainly concentrated in Xicheng Distict, Dongcheng Distict, while partially occurred in Haidian Distict and Chaoyang Distict. The impact of anthropogenic heat gradually intensified from 2003 to 2012 (see Figure 8). By 2012, the concentrations of anthropogenic heat extended to the entire urban area as well as some surrounding suburban regions, showing a great expansion in the past decade (see Figure 7). In urban area, the existence 
of water bodies (e.g. artificial lakes and moats) and constant irrigation for gardens, lawns and other greenbelts provide sufficient water for ET purposes. On the other hand, anthropogenic heat emission from human metabolism, industrial sector, vehicles and buildings contribute greatly to the surface energy budget (Allen et al., 2011; McCarthy et al., 2010; Sailor, 2011). These two reasons above can result in a wet-limit condition (energy at limiting cases), which could be a main ET additional part compared to suburban area. Moreover, domestic water use in the buildings could also be a main additional part of ET. The teeming industrial hubs, vehicle exhaust, and densely populated make the heart of Beijing city particularly concentrated with anthropogenic heat. Therefore, the regions with high value of anthropogenic heat could be the main ET additional parts compared to suburban area. It can also be observed that ET values estimated by SEBS-Urban showed an agreement with water balance-based estimates in urban area, suburban area and plain area, where ET values were underestimated by SEBS (see Figure 6c, 6d, 6e). Specifically, compared to water balance method, a very high correlation coefficient (0.97) as well as small Bias $(-0.24 \%)$ were showed in urban area by SEBS-Urban, while a sharp underestimation in ET values from SEBS was observed in urban area (-46.84\%). In addition, the results from SEBS and SEBS-Urban were approximately equal in mountainous area (see Figure 6b), which were in accord with the fact that the anthropogenic heat-free areas distribute mostly in mountainous area. This provides an insight on how greatly anthropogenic heat impact on ET. Therefore, this heat should be included in the urban surface energy budget for an accurate estimation of ET in the highly urbanized areas.
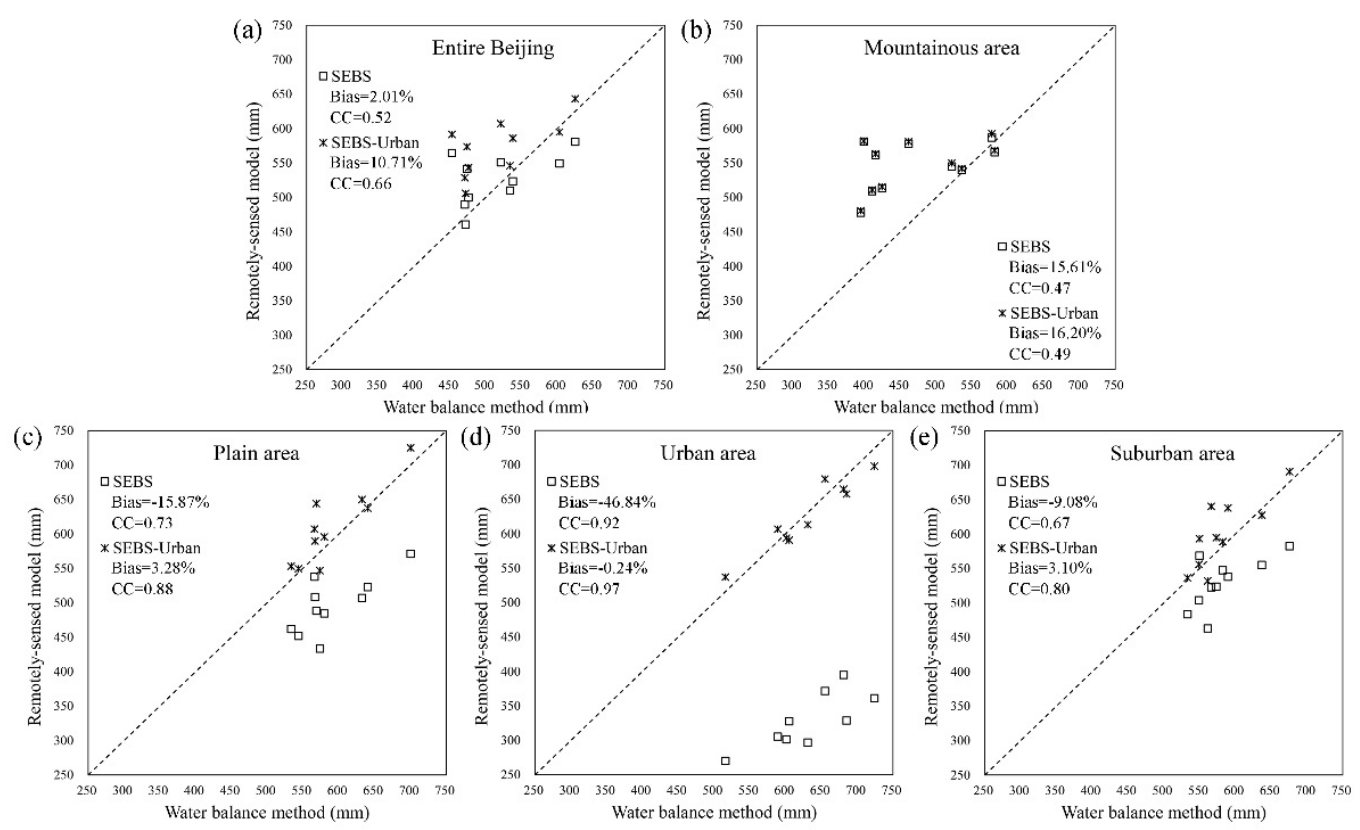

Figure 6. Relationships between ET estimation based on water balance method and remotely-sensed models in subareas of Beijing during 2003-2012. 

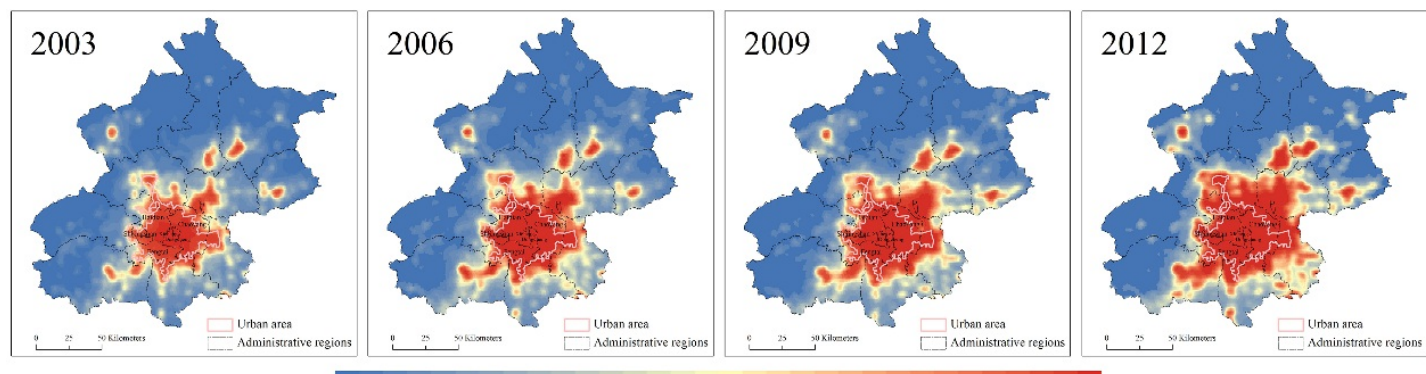

$\begin{array}{lllll}0 & 8 & 16 & 24 & 32\end{array}$

$\begin{array}{llll}40 & 48 & 56 & 63\end{array}$

Figure 7. The distribution of anthropogenic heat-impacted areas in Beijing in the typical years.

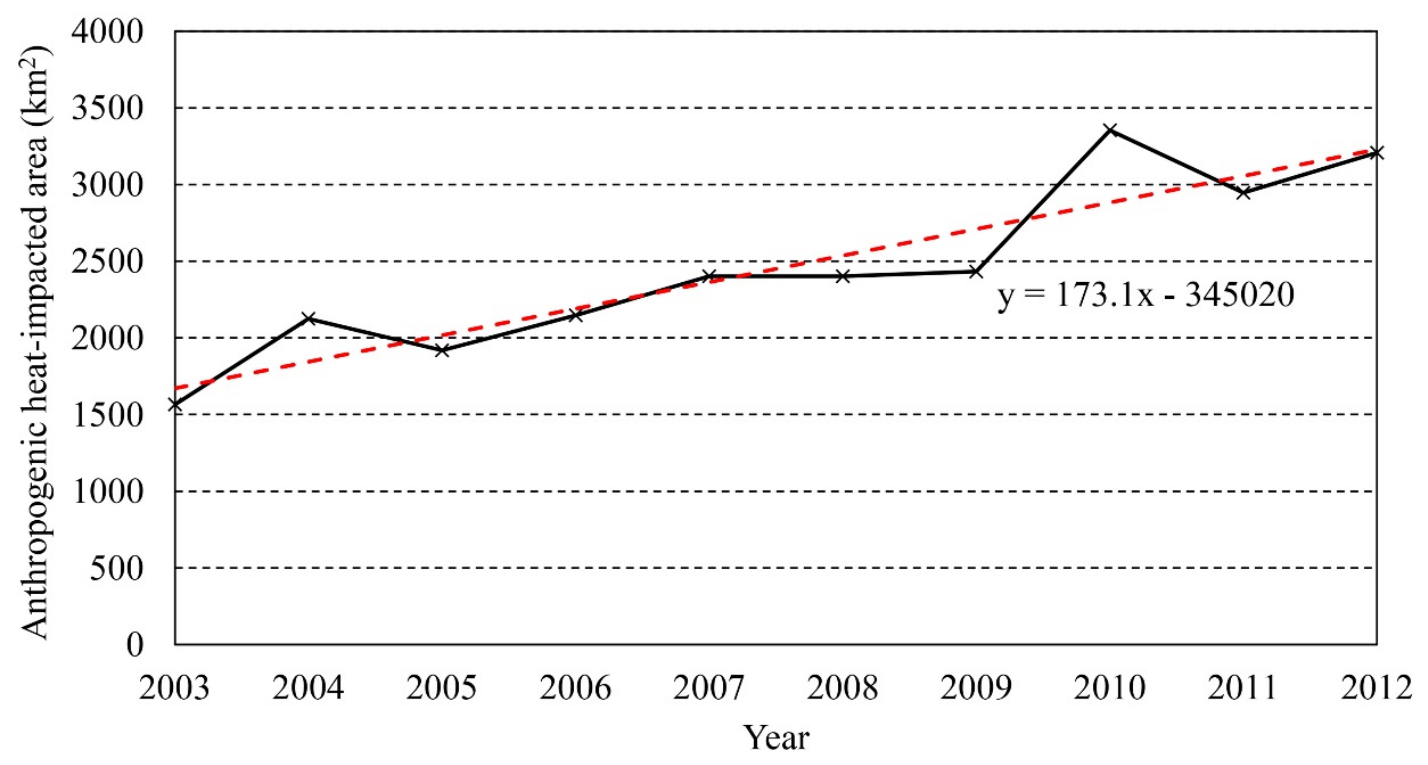

Figure 8. The evolution of anthropogenic heat-impacted areas in Beijing from 2003 to 2012.

\subsection{Uncertainty analysis}

It should be noted that there were some uncertainties existed in ET estimation. As for water balance model, the groundwater inflow was assumed to be equal to groundwater outflow in Beijing city due to the lack of measured data, which would produce uncertainty in ET estimation. Besides, uncertainties could also come from the annual precipitation in subareas, which were estimated according to meterological stations and local precipitation contour map. In remote sensing-based methods, a major concern is the quality of satellite image which are greatly influenced by weather condition in the study region. The uncertainties were somehow generated from the subjective selection of the cloud-free days in the year.

Actually aerosol can contribute to additional large-scale decrease in radiation budget in the metropolises like Beijing (Charlson and Schwartz, 1992; Hansen et al., 1997; Haywood and Shine, 1995; Kushta et al., 1995; Papayannis et al., 1998). In this study, the long time scale extension was based on the ratio of estimated $\mathrm{ET}_{0}$ and the corresponding $\mathrm{ET}_{0}$ for the days of image available, then the actual $\mathrm{ET}$ for days without good quality images could be inferred. Note that aerosol played an essential role in sunshine duration, which has a great influence on net radiation, and then the $\mathrm{ET}_{0}$. Therefore, aerosol effect was not considered in the estimation of cloud-free days ET, 
but was implicitly considered in the crop coefficient method which was used to extend time series of ET. However, the extension of long-time series of ET would lead to some uncertainties if the intervals between images available were not accordance with the actual case.

\section{Conclusions}

In this study, water balance method, energy balance model SEBS and SEBS-Urban were used to estimate ET of Beijing from 2003 to 2012. Our results have shown that:

(1) Based on water balance method, the average ET over 2003 to 2012 was 517 $\mathrm{mm}$ in entire Beijing. The urban area had the highest ET value $(654 \mathrm{~mm})$, while the mountainous area had the lowest value $(472 \mathrm{~mm})$.

(2) Using SEBS model, the annual average ET in urban area was sharply underestimated with a value of $348 \mathrm{~mm}$. By the modified model SEBS-Urban, annual average ET in urban area was the highest among all subareas $(652 \mathrm{~mm})$, while the lowest in mountainous area $(549 \mathrm{~mm})$, which was coincident with the result from water balance method.

(3) Time series of ET estimated by SEBS-Urban showed a good agreement with water balance method in urban area.

The results indicate that anthropogenic heat should be included in the surface energy budget for a highly urbanized area. Further study should focus on detailed analysis on the evaluation of anthropogenic heat as well as the impact of net advection.

\section{Acknowledgements}

This work was supported by the National Natural Science Foundation of China under Grant Number 51279208 and 51179083. The forcing dataset used in this study was developed by Data Assimilation and Modeling Center for Tibetan Multi-spheres, Institute of Tibetan Plateau Research, Chinese Academy of Sciences. We would like to thank Beijing Water Authority, Beijing Municipal Bureau of Statistics, NASA and NOAA for providing data freely. Also we are grateful to Prof. Zongbo Su for the assistance in SEBS programming.

\section{References}

Alexandris S, Stricevic R and Petkovic S, 2008. Comparative analysis of reference evapotranspiration from the surface of rainfed grass in central Serbia, calculated by six empirical methods against the Penman-Monteith formula. European Water, 21(22): 17-28.

Allen L, Lindberg F and Grimmond C, 2011. Global to city scale urban anthropogenic heat flux: model and variability. Int J Climatol, 31(13): 1990-2005.

Allen R G, Morse A, Tasumi M, Bastiaanssen W, Kramber W and Anderson H, 2001. Evapotranspiration from Landsat (SEBAL) for water rights management and compliance with multi-state water compacts. In Geoscience and Remote Sensing Symposium, IGARSS'01. IEEE 2001 International, Vol. 2, pp. 830-833.

Allen R G, 2000. Using the FAO-56 dual crop coefficient method over an irrigated region as part of an evapotranspiration intercomparison study. J Hydrol, 229(1): 27-41.

Allen R G, Pereira L S, Raes D and Smith M, 1998. Crop evapotranspiration-Guidelines for computing crop water requirements-FAO Irrigation and drainage paper 56 . FAO, Rome, 300(9): D05109.

Allen R G, Tasumi M and Trezza R, 2007. Satellite-based energy balance for mapping evapotranspiration with internalized calibration (METRIC)—Model. Journal of 
Irrigation and Drainage Engineering, 133(4): 380-394.

Alley W M, 1984. On the treatment of evapotranspiration, soil moisture accounting, and aquifer recharge in monthly water balance models. Water Resour Res, 20(8): 1137-1149.

Bai X and Imura H, 2001. Towards sustainable urban water resource management: a case study in Tianjin, China. Sustainable Development, 9(1): 24-35.

Bastiaanssen W, Menenti M, Feddes R A and Holtslag A, 1998. A remote sensing surface energy balance algorithm for land (SEBAL). 1. Formulation. J Hydrol, 212: 198-212.

Beljaars A and Holtslag A, 1991. Flux parameterization over land surfaces for atmospheric models. J Appl Meteorol, 30(3): 327-341.

Bratman G N, Daily G C, Levy B J and Gross J J, 2015. The benefits of nature experience: Improved affect and cognition. Landscape and Urban Planning, 138: 41-50.

Brutsaert W, 1982. Evaporation into the Atmosphere-Theory, History and Application. D. Reidel pub. Comp, Dordrecht-Boston-London.

Brutsaert W, 1999. Aspects of bulk atmospheric boundary layer similarity under free convective conditions. Rev Geophys, 37(4): 439-451.

Charlson R J, Schwartz S E, 1992. Climate forcing by anthropogenic aerosols. Science, 255(5043): 423-230.

Che W R, 2008. Annual Water Utilization Estimation of main Trees, Shrubs and Lawn Grass Species of Greenland in Beijing. Master's Dissertation. Beijing: Beijing Forestry University (in Chinese).

DiGiovanni K, Montalto F, Gaffin S and Rosenzweig C, 2012. Applicability of classical predictive equations for the estimation of evapotranspiration from urban green spaces: green roof results. Journal of Hydrologic Engineering, 18(1): 99-107.

Du L X and Xing S H, 2009. Relationship between Spatial Distribution Pattern of Shrub Community and Environmental Factors in Badaling of Beijing. Acta Botanica Boreali-Occidentalia Sinica, 29(3): 601-607 (in Chinese).

Flanner M G, 2009. Integrating anthropogenic heat flux with global climate models. Geophys Res Lett, 36(2).

Gillies R R and Carlson T N, 1995. Thermal remote sensing of surface soil water content with partial vegetation cover for incorporation into climate models. J Appl Meteorol, 34(4): 745-756.

Granier A, Bréda N, Biron P and Villette S, 1999. A lumped water balance model to evaluate duration and intensity of drought constraints in forest stands. Ecol Model, 116(2): 269-283.

Grimmond C S B and Oke T R, 1991. An evapotranspiration - interception model for urban areas. Water Resour Res, 27(7): 1739-1755.

Hansen J, Sato M, Ruedy R, 1997. Radiative forcing and climate response. J Geophys Res: Atmospheres, 102(D6): 6831-6864.

Haywood J M, Shine K P, 1995. The effect of anthropogenic sulfate and soot aerosol on the clear sky planetary radiation budget. Geophys Res Lett, 22(5): 603-606.

He G J, Chen G, He X Y, Wang, W and Liu D S, 2001. Extracting Buildings Distribution Information of Different Heights in a City from the Shadows in a Panchromatic SPOT Image. Journal of Image and Graphics, 6(5): 425-428 (in Chinese).

He J, Yang K. China Meteorological Forcing Dataset. Cold and Arid Regions Science Data Center at Lanzhou, 2011. doi:10.3972/westdc.002.2014.db

Heilig G K, 2012. World urbanization prospects: the 2011 revision. United Nations, Department of Economic and Social Affairs (DESA), Population Division, 
Population Estimates and Projections Section, New York.

Ichinose T, Shimodozono K and Hanaki K, 1999. Impact of anthropogenic heat on urban climate in Tokyo. Atmos Environ, 33(24): 3897-3909.

Iglesias A, Garrote L, Flores F and Moneo M, 2007. Challenges to manage the risk of water scarcity and climate change in the Mediterranean. Water Resources Management, 21(5): 775-788.

Jia L, Xi G, Liu S, Huang C, Yan Y, and Liu G, 2009. Regional estimation of daily to annual regional evapotranspiration with MODIS data in the Yellow River Delta wetland. Hydrol Earth Syst Sci, 13(10): 1775-1787.

Jiang Y, 2009. China's water scarcity. J Environ Manage, 90(11): 3185-3196.

Kłysik K, 1996. Spatial and seasonal distribution of anthropogenic heat emissions in Lodz, Poland. Atmos Environ, 30(20): 3397-3404.

Kushta J, Kallos G, Astitha M, Solomos S, Spyrou C, Mitsakou C, and Lelieveld J, 2014. Impact of natural aerosols on atmospheric radiation and consequent feedbacks with the meteorological and photochemical state of the atmosphere. $J$ Geophys Res: Atmospheres, 119(3): 1463-1491.

Li S S and Yang S N, 2015. Changes of extreme temperature events in Beijing during 1960-2014. Science Geographica Sinica, 35(12): 1640-1647 (in Chinese).

Liang S, 2001. Narrowband to broadband conversions of land surface albedo I: Algorithms. Remote Sens Environ, 76(2): 213-238.

Long D and Singh V P, 2010. Integration of the GG model with SEBAL to produce time series of evapotranspiration of high spatial resolution at watershed scales. J Geophys Res: Atmospheres, 115(D21).

McCarthy M P, Best M J and Betts R A, 2010. Climate change in cities due to global warming and urban effects. Geophys Res Lett, 37(9).

McMahon T A, Peel M C, Lowe L, Srikanthan R and McVicar T R, 2013. Estimating actual, potential, reference crop and pan evaporation using standard meteorological data: a pragmatic synthesis. Hydrol Earth Syst Sci, 17(4): 13311363.

Morse A, Tasumi M, Allen R G and Kramber W J, 2000. Application of the SEBAL methodology for estimating consumptive use of water and streamflow depletion in the Bear River basin of Idaho through remote sensing. Idaho Department of Water Resources-University of Idaho.

Nie W S, Sun T and Ni G H, 2014. Spatiotemporal characteristics of anthropogenic heat in an urban environment: a case study of Tsinghua campus. Build Environ, 82: $675-686$.

Oke T R, 2002. Boundary layer climates. Routledge.

Palmroth S, Katul G G, Hui D, McCarthy H R, Jackson R B, and Oren R, 2010. Estimation of long - term basin scale evapotranspiration from streamflow time series. Water Resour Res, 46(10).

Papayannis A, Balis D, Bais A, Van der Bergh H, Calpini B, Durieux E, Fiorani L, Jaquet L, Ziomas I, and Zerefos C S, 1998. Role of urban and suburban aerosols on solar UV radiation over Athens, Greece. Atmos Environ, 32(12): 2193-2201.

Paul M J and Meyer J L, 2008. Streams in the urban landscape. Springer, pp. 207-231.

Penman H L, 1948. Natural evaporation from open water, bare soil and grass. The Royal Society, pp. 120-145.

Pigeon G, Legain D, Durand P and Masson V, 2007. Anthropogenic heat release in an old European agglomeration (Toulouse, France). Int J Climatol, 27(14): 19691981.

Priestley C and Taylor R J, 1972. On the assessment of surface heat flux and evaporation 
using large-scale parameters. Mon Weather Rev, 100(2): 81-92.

Roerink G J, Su Z and Menenti M, 2000. S-SEBI: A simple remote sensing algorithm to estimate the surface energy balance. Phys Chem Earth, Part B: Hydrology, Oceans and Atmosphere, 25(2): 147-157.

Sailor D J, 2011. A review of methods for estimating anthropogenic heat and moisture emissions in the urban environment. Int J Climatol, 31(2): 189-199.

Sailor D J and Lu L, 2004. A top-down methodology for developing diurnal and seasonal anthropogenic heating profiles for urban areas. Atmos Environ, 38(17): 2737-2748.

Senay G B, Leake S, Nagler P L, Artan G, Dickinson J, Cordova J T, and Glenn E P, 2011. Estimating basin scale evapotranspiration (ET) by water balance and remote sensing methods. Hydrol Process, 25(26): 4037-4049.

Shi Y F, Wang X Q, Sun Z H, Chen Y Z and Fu Q K, 2015. Urban Building Heights Estimation from the Shadow Information on ZY-3 Images. Journal of Geoinformation Science, 17(2): 236-243 (in Chinese).

Shu S, Yu B L, Wu J P and Liu H X, 2011. Methods for deriving urban built up area using night light data: Assessment and application. Remote Sens Technol Appl, 26: 169-176 (in Chinese).

Song Z W, Zhang H L, Huang J and Chen F, 2009. Characters of Water Requirement for Main Crops and Field Water Balance in Beijing Region. Research of Agricultural Modernization, 30(4): 461-465 (in Chinese).

Su Z, 2002. The Surface Energy Balance System (SEBS) for estimation of turbulent heat fluxes. Hydrology and Earth System Sciences Discussions, 6(1): 85-100.

Su Z, Schmugge T, Kustas W P and Massman W J, 2001. An evaluation of two models for estimation of the roughness height for heat transfer between the land surface and the atmosphere. J Appl Meteorol, 40(11): 1933-1951.

Sugita M and Brutsaert W, 1991. Daily evaporation over a region from lower boundary layer profiles measured with radiosondes. Water Resour Res, 27(5): 747-752.

Sumner D M and Jacobs J M, 2005. Utility of Penman-Monteith, Priestley-Taylor, reference evapotranspiration, and pan evaporation methods to estimate pasture evapotranspiration. J Hydrol, 308(1): 81-104.

Tam B Y, Gough W A and Mohsin T, 2015. The impact of urbanization and the urban heat island effect on day to day temperature variation. Urban Climate, 12: 1-10.

Tong H, Liu H Z, Sang J G and Hu F, 2004. The Impact of Urban Anthropogenic Heat on Beijing Heat Environment. Climatic and Environmental Research, 9(3): 409421 (in Chinese).

Van den Hurk B and Holtslag A, 1997. On the bulk parameterization of surface fluxes for various conditions and parameter ranges. Bound-Layer Meteor, 82(1): 119-133.

Wang Y and Wang H, 2005. Sustainable use of water resources in agriculture in Beijing: problems and countermeasures. Water Policy, 7(4): 345-357.

$\mathrm{Xu} \mathrm{C}$ and Singh V P, 2005. Evaluation of three complementary relationship evapotranspiration models by water balance approach to estimate actual regional evapotranspiration in different climatic regions. J Hydrol, 308(1): 105-121.

Xu M Y, Li Y Q, Wang K, Cao Y F, Yu H L, Li X F, Li L S, Jing F J, Li J X and Xie F, 2009. Spatial distribution and dynamic characteristics of the grassland vegetation in Hebei. Acta Prataculturae Sinica, 18(6): 1-11 (in Chinese).

Yang J, Wang Z H, Chen F, Miao S, Tewari M, Voogt J A and Myint S, 2015. Enhancing Hydrologic Modelling in the Coupled Weather Research and Forecasting-Urban Modelling System. Bound-Layer Meteor, 155(1): 87-109.

Yang L, Niyogi D, Tewari M, Aliaga D, Chen F, Tian F Q and Ni G H, 2016. Contrasting 
impacts of urban forms on the future thermal environment: example of Beijing metropolitan area. Environ Res Lett, 11(3): 034018.

You H L, Ren G Y, Liu W D, 2012. Precipitation changes over the beijing area during 1961-2010. Desert and Oasis Meteorology, 6(4): 13-20 (in Chinese).

Zhang C L, Chen F, Miao S G, Li Q C, Xia X A and Xuan C Y, 2009. Impacts of urban expansion and future green planting on summer precipitation in the Beijing metropolitan area. J Geophys Res: Atmospheres, 114(D2).

Zhang L J, Sun C Z, Xin X B and Kong Q Y, 2014. Allometric relationship between height and diameter at breast height of different stand in Beijing Jiulong mountain. Journal of Central South University of Forestry \& Technology, 34(12): 66-70 (in Chinese).

Zhang X W, 2011. Studies on the canopy structrue of plant communities in some Beijing greenbelt. Master's Dissertation. Beijing: Beijing Forestry University (in Chinese).

Zheng W W, 2012. Inversion of evapotranspiration on urban land surface based on remote sensing data. Doctoral Dissertation. Changsha: Central South University (in Chinese).

Zhong S, Qian Y, Zhao C, Leung R and Yang X Q, 2015. A case study of urbanization impact on summer precipitation in the Greater Beijing Metropolitan Area: Urban heat island versus aerosol effects. J Geophys Res: Atmospheres, 120(20). 